\title{
SYNTHESIS OF THE NOISE IMMUNE ALGORITHM FOR ADAPTIVE CONTROL OF ORE CONCENTRATION
}

Morkun V. S. - Dr. Sc., Professor, Vice-Rector for research, Kryvyi Rih National University, Kryvyi Rih, Ukraine.

Morkun N. V. - Dr. Sc., Associated Professor, Head of the Department of Automation, Computer Science and Technology Kryvyi Rih National University, Kryvyi Rih, Ukraine.

Hryshchenko S. M. - PhD, Head of Post-graduate and Doctoral Education Department, Kryvyi Rih National University, Kryvyi Rih, Ukraine.

Tron V. V. - PhD, Associated Professor, Associated Professor of the Department of Automation, Computer Science and Technology, Kryvyi Rih National University, Kryvyi Rih, Ukraine.

\section{ABSTRACT}

Context. Consideration of the transient process characteristics under current industrial conditions, i.e. a controlled object's static and dynamic characteristics when forming controlling impacts in automatic control systems of ore grinding and sizing is one of the advanced ways to increase their efficiency.

Variations in characteristics of initial materials and equipment conditions while changing a command value in closed-loop automatic control systems (ACS) result in transient processes when the granularmetric composition of output products of grinding and sizing aggregates change in a wide range. It leads to additional losses of the recovered grade.

Duration of transient processes depends on how the controlled object's current condition (its static and dynamic characteristics) corresponds to the controller's adjustment in the ACS. It causes the necessity to readjust the controller's parameters from time to time that is done in the adaptive ACS to the best advantage.

The authors suggest an algorithm of noise immune correction of the controller's parameters in the closed-loop automatic control system, which is based on preliminary identification of the controlled object's static and dynamic characteristics in accordance with parameters of the transient process starting in the closed-loop ACS of the transient process. There are determined limits to its applicability at concentration plants.

Objective. The research aims to develop a noise immune algorithm of adaptive control over objects with variable static and dynamic characteristics on the basis of the controlled parameter value and the rate of its changes on the initial stage of transient processes in the closed-loop ACS.

Method. Current approaches and methods of improving ore concentration control are analyzed to substantiate the research topicality, goals and objectives. The adaptation algorithm for local ACS of ore concentration is synthesized and analyzed by methods of analytical design and computer simulation.

Results. Correction of the PI-controller according to the suggested algorithm reduces the transient time in the closed-loop ACS. It should be done at the moment determined by the condition $\dot{X}\left(t_{\Pi}\right)=0$ even in case of the optimal adjustment. The polynomial presentation degree of the filter should not be lower than 2, i.e. $m \geq 2$. In this case, filtration is satisfactory if fluctuation of the output signal does not exceed $25 \%$ of its absolute value because of noises.

Conclusions. The theory of forming specified parameters of transient processes in the closed-loop ACS by means of objects with variable static and dynamic characteristics on the basis of the controlled parameter value and the rate of its changes on the initial stage of these processes is developed in the present research. It allows synthesizing adaptive ACS, in which the error ratio in the transient process reaches zero in a minimum of time without changing its sign subject to disturbances and noises.

KEYWORDS: closed-loop system, regulation, control, algorithm, transient, adaptation, validity limits.

\begin{abstract}
ABBREVIATIONS
ACS is an automatic control systems; NFN is a neuro-fuzzy network; PI is a proportionally integral;
\end{abstract}

\section{NOMENCLATURE}

$K_{o}$ is a coefficient of the controlled object transfer function;

$T_{o}$ is a time constant of the controlled object transfer function;

$\tau$ is a time delay;

$Y(t)$ is a measured value;

$X^{(\mathrm{i})}(t)$ is a input value;

$T$ is a measurement interval;

$K_{\mathrm{n}}^{t_{\mathrm{n}}}$ is a coefficient of the controller transfer function;

$T_{n}^{t_{n}}$ is a time constant of the controller transfer function;
$\bar{X}_{i}$ is a filtered value of the input value;

$\bar{Y}_{i}$ is a filtered value of the measured value;

$F_{j}(t)$ is a orthogonal $j$-th order polynomials;

$t_{\mathrm{\Pi}}$ is a shift moment;

$\sigma$ is a noise intensity.

\section{INTRODUCTION}

Variations in characteristics of initial materials and equipment conditions while changing a command value in closed-loop automatic control systems (ACS) result in transient processes when the granularmetric composition of output products of grinding and sizing aggregates change in a wide range. It leads to additional losses of the recovered grade. Duration of transient processes depends on how the controlled object's current condition (its static and dynamic characteristics) corresponds to the controller's adjustment in the ACS. It causes the necessity 
to readjust the controller's parameters from time to time that is done in the adaptive ACS to the best advantage.

The object of study is to develop a noise immune algorithm of adaptive control over objects with variable static and dynamic characteristics on the basis of the controlled parameter value and the rate of its changes on the initial stage of transient processes in the closed-loop ACS.

The purpose of the work is to increase efficiency of control of ore grinding and sizing processes.

\section{PROBLEM STATEMENT}

Current flow sheets of automation of grinding and classifying aggregates of concentration plants are based on local automatic control systems, which maintain designed values of controlled parameters. Efficiency of such control systems is conditioned by initial information on a controlled process.

Research works [1-3] present the objective function of controlling ore grinding and classifying as follows:

$$
\begin{gathered}
Q_{\mathrm{p}} \rightarrow \max Q_{\mathrm{p}} \geq Q_{\mathrm{p} \text { set}}, \\
\beta_{-0,074}=\beta_{-0,074 \text { set }},
\end{gathered}
$$

i.e., there is a formulated requirement of maximum (or no lower than the desired one) efficiency of ore processing equipment and the limit of the content (yield) of the control size class of the ground material is introduced.

The most efficient automatic control systems are those based on regulation or maintenance of the desired content of the control size class of the solid material in slurry considering granulometer signals. Research works [4-6] indicate that such ACS allow applying grinding capacities more efficiently due to permanent load, maintenance of the circulating load value necessary to obtain the required grind and improving concentration quality due to manufacturing the product of the grinding circuit with desired characteristics. In case of using an automatic granulometer in ACS, the regulation strategy is based on two approaches:

- maintaining the permanent size of the ground ore in the classifier overflow product слива классификатора;

- regulating the power value in the grinding circuit цикле измельчения to maintain the maximum load of the grinding aggregate.

One of the conditions of the objective function (1) $Q_{\mathrm{p}} \geq Q_{\text {p.set }}$ can be fulfilled by current control systems to stabilize the grinding aggregate filling or the quantity of the initial raw materials coming to the grinder. To make technological aggregates more efficient it is necessary to influence the command value, i.e. to change the stabilization level of these control systems.

The second condition of the objective function (2) $\beta_{-0,074}=\beta_{-0,074 \text { set }}$ is fulfilled more efficiently by ACS with a granulometer realizing the measuring method presented in $[7,8]$. The exact value of the control size class content of the ground material in slurry is determined by the useful (C) Morkun V. S., Morkun N. V., Hryshchenko S. M, Tron V. V., 2018 DOI 10.15588/1607-3274-2018-3-20 component content, which is measured by methods presented in $[9,10]$.

The changed command value in systems of automatic stabilization of technological parameters and various disturbances cause transient processes the character and duration of which are determined by current characteristics of the controlled object. During transient processes, the condition (2) of the reduced criterion is fulfilled with considerable errors.

Thus, consideration of transient characteristics for a current production situation, i.e. actually static and dynamic characteristics of a controlled object in forming controlling impacts in automatic control systems is one of the promising ways to increase efficiency of ore grinding and classifying.

\section{REVIEW OF THE LITERATURE}

Adaptive control algorithms realizing this approach provide for preliminary identification of static and dynamic characteristics of the controlled object and further correction of the controller parameters according to obtained estimates [10-12].

This approach allows reducing the operation time of technological aggregates in transient modes when there are considerable deviations of qualitative and quantitative characteristics of their end products from optimal values.

Research works [9, 13] and some others investigate variations of static and dynamic characteristics of grinding aggregates by command links under the influence of disturbing factors. For example, according to the command link "water consumption in the classifier the content of the control size class of solid materials in the classifier overflow" the range of the changed static transfer coefficient makes $\pm 75-80 \%$, that of the time constant is $\pm 10-16 \%$ and that of delay time is $\pm 5 \%$.

Optimal conditions of correcting PI-controller parameters presented in works [14-16] indicate that the transient process caused by changing the command value in closed-loop ACS will be completed in a minimum of time under the absence of its oscillation or its minimum.

Works [17-20] provide mathematical expressions on the basis of which an adaptation algorithm for automatic control systems is synthesized, the transfer function of which is approximated by

$$
W_{\mathrm{o}}(P)=\frac{K_{\mathrm{o}} e^{-\tau p}}{T_{\mathrm{o}} P+1},
$$

where $K_{\mathrm{o}}$ и $T_{\mathrm{o}}$ are the statistic transfer function and the time constant of the controlled object; $\tau$ is time delay.

The adaptation algorithm is based on preliminary identification of static and dynamic characteristics of the controlled object by parameters of the transient process, which started in the closed-loop ACS in accordance with the following expressions

$$
T_{\mathrm{o}}=\frac{\lambda_{\mathrm{o}}^{2}-\aleph_{\mathrm{oo}} \eta}{\aleph_{10} \eta-\lambda_{\mathrm{o}} \lambda_{1}},
$$




$$
K_{\mathrm{o}}=\frac{\aleph_{10} \lambda_{\mathrm{o}}-\aleph_{\mathrm{oo}} \lambda_{1}}{\aleph_{10} \eta-\lambda \lambda_{1}}
$$

where

$$
\begin{aligned}
& \aleph_{i j}=\sum_{k=1}^{N+1} X_{k}^{(j)} X_{k}^{(i)} ; \\
& \lambda_{j}=\sum_{k=1}^{N+1} X_{k}^{(j)} Y_{k} ; \\
& \eta=\sum_{k=1}^{N+1} Y_{k}^{2} .
\end{aligned}
$$

$Y(t)$ and $X^{(i)}(t)$ are measured values and if the transient process is initiated by abrupt changes of the input value

$$
Y(t)=-K_{\text {п }}\left[X(t)+\frac{1}{T_{\text {и }}} \int_{o}^{t} X\left(t^{\prime}\right) d t^{\prime}\right],
$$

If the command value is changed

$$
Y(t)=K_{\text {п }}\left[(g-X(t))+\frac{1}{T_{\text {и }}} \int_{o}^{t}\left[\left(g-X\left(t^{\prime}\right)\right] d t^{\prime}\right],\right.
$$

The values of $Y(t)$ and $X^{(\mathrm{i})}(t)$ functions are changed in discrete moments of time in some period $(O, N T)$, where $T$ is a measurement interval.

In arbitrary time moments $t_{\mathrm{a}}$, parameters of the PI-controller are corrected so that the following condition is fulfilled:

a) the control error function $\varepsilon(t)$ should not be alternating;

b) the control error should reach the zero value in the shortest time.

In case of abrupt changes of the input value, the PIcontroller parameters are corrected according to

if $\tau \approx 0$

$$
\begin{gathered}
K_{\Pi}^{+t_{\Pi}}=2\left[K_{\Pi}^{-t_{\Pi}}+\frac{g+Y_{-}\left(t_{\Pi}\right)}{X\left(t_{\Pi}\right)}\right]-\frac{1}{K_{o}}, \\
T_{\text {и }}^{+t_{\Pi}}=T_{o} \frac{4 K_{\Pi}^{+t_{\Pi}} K_{o}}{\left(1+K_{\Pi}^{+t_{\Pi}} K_{o}\right)^{2}},
\end{gathered}
$$

if $\tau \neq 0$

$$
\begin{aligned}
& K_{\mathrm{n}}^{+t_{n}}=\frac{2\left\{K_{\mathrm{\pi}}^{+t_{n}} \tilde{X}\left(t_{\pi}\right)+g+Y \_\left(t_{\pi}\right)\right\}}{\tilde{X}\left(t_{\mathrm{n}}\right)-\dot{\tilde{X}}\left(t_{\mathrm{n}}\right) \tau}- \\
& -\frac{1}{K_{o}} \frac{\tilde{X}\left(t_{\mathrm{m}}\right)+\dot{\tilde{X}}\left(t_{\mathrm{\Pi}}\right) \tau}{\tilde{X}\left(t_{\mathrm{\Pi}}\right)-\dot{\tilde{X}}\left(t_{\mathrm{\Pi}}\right) \tau},
\end{aligned}
$$

where $\tilde{X}(t) \approx X(t-\tau)$.

In this case, the value of $T_{\mathrm{u}}^{+t_{\mathrm{n}}}$ is also determined by formula (9).

If the command value is changed, the controller parameters are corrected in accordance with the following expressions

if $\tau \approx 0$

$$
K_{\mathrm{\Pi}}^{+t_{\mathrm{n}}}=2\left[K_{\mathrm{\Pi}}^{-t_{\mathrm{n}}}+\frac{X\left(t_{\mathrm{n}}\right) K_{\mathrm{o}}^{-1}-Y_{-}\left(t_{\mathrm{n}}\right)}{\varepsilon\left(t_{\mathrm{n}}\right)}\right]+\frac{1}{K_{o}},
$$

$$
T_{\mathrm{u}}^{+t_{\mathrm{n}}}=T_{\mathrm{o}} \frac{4 K_{\mathrm{o}} K_{\mathrm{I}}^{+t_{\mathrm{I}}}}{\left(1+K_{\mathrm{o}} K_{\mathrm{\Pi}}^{+t_{\mathrm{n}}}\right)^{2}}
$$

if $\tau \neq 0$

$$
K_{\mathrm{n}}^{+t_{\mathrm{n}}}=2\left\{\frac{K_{\mathrm{n}}^{-t_{\mathrm{n}}} \varepsilon\left(t_{\mathrm{n}}\right)+X\left(t_{\mathrm{\Pi}}\right) K_{o}^{-1}-Y_{-}\left(t_{\mathrm{n}}\right)}{\varepsilon\left(t_{\mathrm{m}}-\tau\right)}\right\}+\frac{1}{K_{o}},
$$

In this case, the value of $T_{\mathrm{u}}^{+t_{n}}$ is determined according to expression (12).

The Purpose of the Article. The research is aimed at determining validity limits of the given adaptation algorithm, i.e. conditions under which the satisfactory quality of condition (2) fulfillment remains if there are changed static and dynamic characteristics of the controlled object and various disturbances and noises in the input signal.

\section{MATERIALS AND METHODS}

The above mentioned adaptation algorithm is aimed at applying in the system controlling the object the transfer function of which is approximated by one relaxation circuit with time delay. Yet, for some technological aggregates of concentration plants, the following expression is true

$$
W_{o}(P)=\frac{K_{o} e^{-\tau p}}{\left(T_{o 1} P+1\right)\left(T_{o 2} P+1\right)},
$$

the ratio $T_{\mathrm{o} 1}$ and $T_{\mathrm{0} 2}$ does not always meet the condition $T_{01} \gg>T_{02}$.

The inverse Laplace transformation for $X(P)$ from expression (14) leads to the integral representation of $X(t)$ value

$$
X(t)=\frac{K_{o}}{T_{01}-T_{02}} \int_{o}^{t-\tau}\left[e^{\frac{t-\tau-u}{T_{01}}}-e^{\frac{t-\tau-u}{T_{02}}}\right] Y(u) d u,
$$

The conducted research is aimed at determining the limit value of the ratio $T_{02} \cdot T_{01}^{-1}$ under which correction by formulae (8) and (10) is possible. This task is solved by modelling the transient process of the object with the transfer function (14) accompanied by further correction of the controller parameters according to (8)-(10).

Some analysis results are given in fig. 1, which reveals transient processes and corrected parameters of the controller in various time moments under different ratio of values $T_{01}$ and $T_{02}$.

As is shown in the figures under $T_{02} \cdot T_{01} \leq 0.2$, the controller parameters corrected by formulae (8) and (10) generally meet correction requirements, namely, they greatly reduce the transient duration. It should be noted that, in this case, the alternating character of the controlled value $X(t)$ cannot be avoided, yet, its oscillation amplitude is not great.

The controller parameters should be corrected even if they are optimal, i.e. they meet the conditions

$$
K_{\mathrm{o}} \cdot K_{\text {пा }}=1 ; T_{01} \approx T_{\text {и }} \text {. }
$$




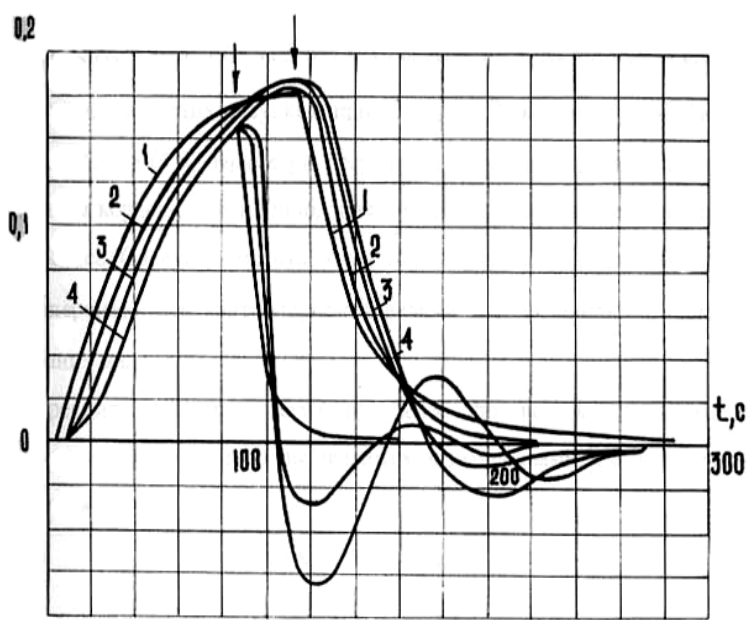

Figure 1 - Correction of the controller parameters:

$1-T_{02} / T_{01}=0 ; K_{\Pi}^{+\mathrm{t}_{\mathrm{n}}}=5.62 ; T_{\mathrm{n}}=48.6 \mathrm{sec} ; 2-T_{02} / T_{01}=0.1 ;$ $K_{\text {п }}^{+\mathrm{t}_{\mathrm{n}}}=5.63 ; T_{\mathrm{r}}=48.6 \mathrm{sec} ; 3-T_{02} / T_{01}=0.2 ; K_{\text {п }}^{+\mathrm{t}_{\mathrm{n}}}=5.72 ; T_{\mathrm{n}}=48.4$ sec; $4-T_{02} / T_{01}=0.3 ; K_{\Pi}^{+\mathrm{t}_{\mathrm{n}}}=5.97 ; T_{\mathrm{и}}=48.1 \mathrm{sec} ; \tau=10 \mathrm{sec} ;$ $K_{\mathrm{o}}=0.25 ; K_{\mathrm{n}}=1 ; T_{\mathrm{n}}=50 \mathrm{sec} ; T_{01}=50 \mathrm{sec}$

It is shown in fig. 2, which depicts the transient process of an object with optimal controller parameters.

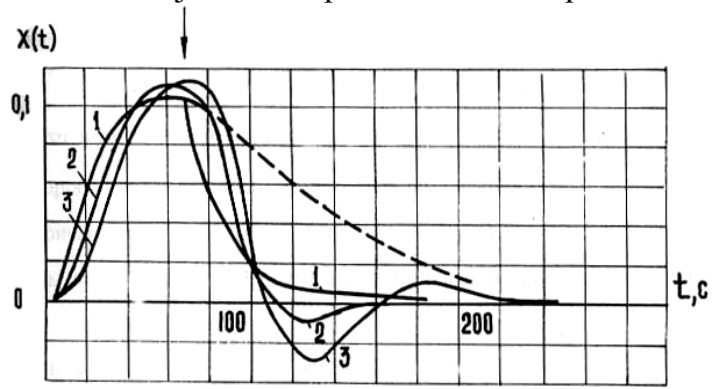

Figure 2 - Correction of the controller parameters $1-T_{02} / T_{01}=0 ; K_{\mathrm{n}}=9.31 ; T_{\mathrm{n}}=42.0 \mathrm{sec} ; 2-T_{02} / T_{01}=0.1 ; K_{\mathrm{n}}=9.0$; $T_{\mathrm{n}}=42.6 \mathrm{sec} ; 3-T_{02} / T_{01}=0.2 ; K_{\mathrm{n}}=9.73 ; T_{\mathrm{n}}=41.3 \mathrm{sec} ; \tau=10 \mathrm{sec} ;$ $K_{\mathrm{o}}=0.25 ; K_{\mathrm{I}}=4 ; T_{\mathrm{n}}=50 \mathrm{sec} ; T_{01}=50 \mathrm{sec}$

Correction can be more steady if it is conducted in the moment when the controlled value $X(t)$ reaches its maximum. This moment can be determined from the condition $\dot{X}(t)=0$. While performing the correction in the given moment, the oscillations of $X(t)$ will occur with the minimum amplitude. It is shown in fig. 1 which presents dependencies of $X(t)$ after correction of the controller parameters in various time moments.

As the analysis results reveal, it is also true for applied expressions (11)-(13).

\section{EXPERIMENTS}

The above principles are realized while synthesizing the noise immune adaptive control algorithm of ore concentration.

In this case, in order to determine the system parameters the values of $x(t), y(t), \varepsilon(t)$ in discrete time moments of $0, T, 2 T, \ldots, N T$ are measured. Corresponding values of $x(t), y(t), \varepsilon(t)$ in these moments form arrays of $\left[x_{i}\right],\left[y_{i}\right],\left[\varepsilon_{i}\right], i=1,2, \ldots, N+1$.

(C) Morkun V. S., Morkun N. V., Hryshchenko S. M, Tron V. V., 2018 DOI 10.15588/1607-3274-2018-3-20
To filtrate random processes $x(t), y(t), \varepsilon(t)$ and determine the system parameters of $K_{\mathrm{o}}$ and $T_{\mathrm{o}}, K_{\Pi}^{+t_{\Pi}}$ and $T_{\text {И }}^{+t_{\text {п }}}$ three matrices of coefficients are specified: $A \equiv\left[a_{i j}\right]$, $C \equiv\left[c_{i j}\right], B \equiv\left[b_{j c}\right]$.

For $N=8$ and $m=3$

$$
\begin{aligned}
& A=\left|\begin{array}{cccc}
1 & 1 & 1 & 1 \\
1 & 3 / 4 & 1 / 4 & -1 / 2 \\
1 & 1 / 2 & -2 / 7 & -13 / 14 \\
1 & 1 / 4 & -17 / 28 & -9 / 14 \\
1 & 0 & -5 / 7 & 0 \\
1 & -1 / 4 & -17 / 28 & 9 / 14 \\
1 & -1 / 2 & -2 / 7 & 13 / 14 \\
1 & -3 / 4 & 1 / 4 & 1 / 2 \\
1 & -1 & 1 & -1
\end{array}\right|, \\
& B=\mid 9 \text { 15/4 99/28 495/98 |, } \\
& -1 / 4 \quad-6 / 7 \quad-181 / 84 \\
& -1 / 4 \quad-9 / 14 \quad-19 / 21 \\
& \begin{array}{lll}
-1 / 4 & -3 / 7 & -1 / 84
\end{array} \\
& \begin{array}{lll}
-1 / 4 & -3 / 14 & 11 / 21
\end{array} \\
& \begin{array}{lll}
-1 / 4 & 0 & 59 / 84
\end{array} \\
& -1 / 4 \quad 3 / 14 \quad 11 / 21 \\
& \begin{array}{lll}
-1 / 4 & 3 / 7 & -1 / 84
\end{array} \\
& \begin{array}{lll}
-1 / 4 & 9 / 14 & 19 / 21
\end{array} \\
& -1 / 4 \quad 6 / 7 \quad-181 / 84
\end{aligned}
$$

The system parameters $K_{\mathrm{o}}$ and $T_{\mathrm{o}}$ and those of the controller $K_{\Pi}^{t_{\Pi}}$ and $T_{\mathrm{U}}^{t_{\Pi}}$ are determined in the following sequence:

1. The values of the coefficients $\alpha_{j}, \beta_{j}$ and $\gamma_{j}$ are found by formulae

$$
\begin{aligned}
& \alpha_{j}=\sum_{i=1}^{9} X_{i} a_{i j} / b_{j}, \\
& \beta_{j}=\sum_{i=1}^{9} Y_{i} a_{i j} / b_{j}, \\
& \gamma_{j}=\sum_{i=1}^{9} \varepsilon_{i} a_{i j} / b_{j} .
\end{aligned}
$$

2. Filtered values of the measured $\bar{X}_{i}, \bar{Y}_{i}$ and derivatives $\dot{\bar{X}}_{i}$ are determined in the same time moments

$$
\begin{aligned}
& \bar{X}_{i}=\sum_{j=1}^{4} \alpha_{j} a_{i \mathrm{j}}, \\
& \bar{Y}_{i}=\sum_{j=1}^{4} \beta_{j} a_{i \mathrm{j}}, \\
& \dot{\bar{X}}_{i}=\frac{1}{T} \sum_{j=1}^{4} \alpha_{j} C_{i \mathrm{j}}, i=1,2, \ldots, 9 .
\end{aligned}
$$

Linear filtration is used with representation of the average value of the signal $f(t)$ in some time interval as 


$$
<f(t)>=\sum_{j=0}^{m} a_{j} F_{j}(t)
$$

where $F_{j}(t)$ are orthogonal $j$-th order polynomials; $a_{j}$ are real coefficients.

3. The system parameters $K_{\mathrm{o}}$ and $T_{\mathrm{o}}$ are determined.

$$
\begin{gathered}
T_{\mathrm{o}}=\frac{\left(\aleph_{0} \eta-\lambda_{\mathrm{o}}^{2}\right)}{\left(\lambda_{\mathrm{o}} \lambda_{1}-\aleph_{1} \eta\right)}, \\
K_{\mathrm{o}}=\frac{\left(\aleph_{0} \lambda_{1}-\aleph_{1} \lambda_{\mathrm{o}}\right)}{\left(\lambda_{\mathrm{o}} \lambda_{1}-\aleph_{1} \eta\right)},
\end{gathered}
$$

Where

$$
\begin{gathered}
\aleph_{o}=\sum_{k=1}^{m} \dot{\bar{X}} \bar{X}_{\mathrm{k}} ; \\
\lambda_{\mathrm{o}}=\sum_{k=1}^{m} \bar{X}_{k} \bar{Y}_{k} ; \\
\aleph_{1}=\sum_{k=1}^{m} \dot{\bar{X}}_{k} \bar{X}_{k} ; \\
\lambda_{1}=\sum_{k=1}^{m} \dot{\bar{X}}_{k} Y_{k}, \quad m \leq N ; \\
\eta=\sum_{k=1}^{m} \bar{Y}_{k} \bar{Y}_{k} ; \\
\bar{X}_{k}=\bar{X}_{\left(t_{k}+\tau\right) ;} \\
\dot{\bar{X}}_{\mathrm{k}}=\dot{\bar{X}}_{\left(t_{k}+\tau\right) ;} \\
\bar{Y}_{k}=\bar{Y}\left(t_{k}\right) .
\end{gathered}
$$

Time moments $\left(t_{k}\right)$ can coincide with measurement moments of the value of $(t), Y(t)$ and $y(t)$, i.e. $\left(t_{k}\right)=i T$, $t_{k}+1=(i+1) T$, etc.

4. The controller parameters are corrected, i.e. their optimal values are determine by

$$
K_{\Pi}^{+t_{\mathrm{n}}}=\frac{1}{K_{o}}+2\left\{\frac{K_{\mathrm{\Pi}}^{-t_{\mathrm{n}}} \varepsilon\left(t_{\mathrm{\Pi}}\right)+X\left(t_{\mathrm{\Pi}}\right) / K_{o}-Y_{-}\left(t_{\mathrm{\Pi}}\right)}{\varepsilon\left(t_{\mathrm{\Pi}}-\tau\right)}\right\},
$$

where $t_{\Pi}$ is the shift moment which can coincide with the last measurement moment, i.e. $t_{\mathrm{n}}=N t$ (the time reading starts from the first measurement moment).

\section{RESULTS}

Fig. 3-4 reveal correction results after preliminary filtration and identification of the object characteristics. Identification was performed in the manner described above.

The results in Fig. 3-4 correspond to the noise intensity of $\sigma=0.01 ; 0.05$. The change in the command value corresponds to the unit step $(g=1)$.

C Morkun V. S., Morkun N. V., Hryshchenko S. M, Tron V. V., 2018 DOI 10.15588/1607-3274-2018-3-20

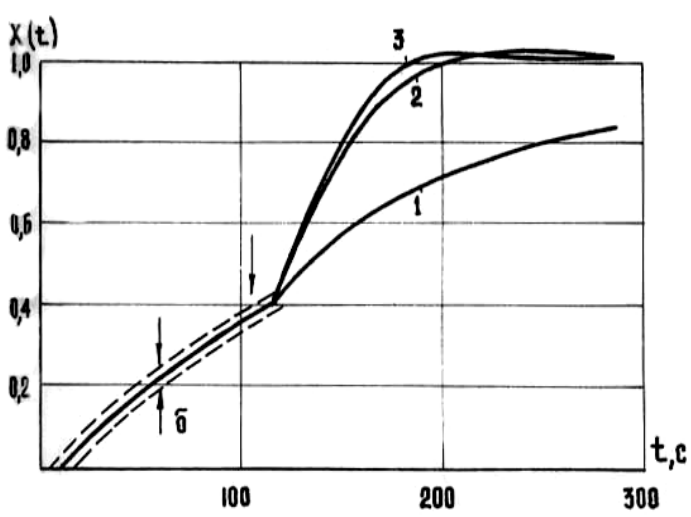

Figure 3 - Correction results of the controller parameters after preliminary filtration and identification of the object characteristics. The noise intensity is $\sigma=0.01$

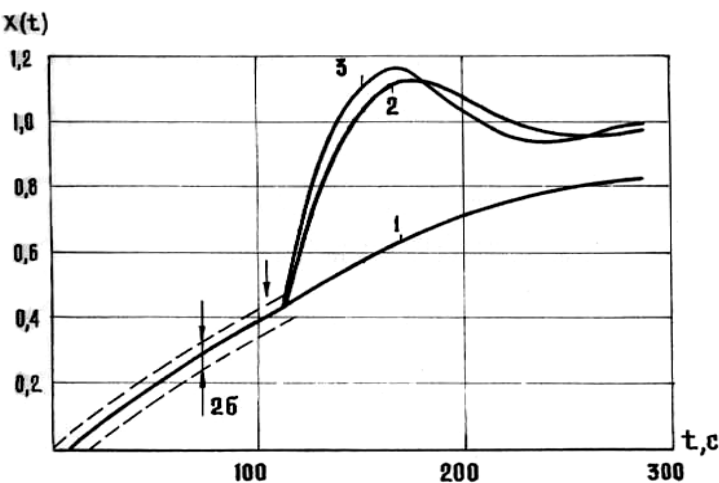

Figure 4 -Correction results of the controller parameters after preliminary filtration and identification of the object characteristics. The noise intensity is $\sigma=0.05$

\section{DISCUSSION}

Under the noise intensity of $\sigma=0.01$ corresponding to $5 \%$ fluctuations of the value $X(t)$ filtration (under $m \geq 2$ ) and further identification produce good results (fig. 3). The increased noise intensity finally affects correction results. In this case, correction also reduces the transient duration, but the controlled value appears in the new established mode oscillating with the amplitude the value of which greatly depends on the noise intensity (fig. 4).

As the observed value of $\mathrm{Z}(t)$ is measured within the time interval $(0, N T)$ in the discrete time moments $0, T, 2 T, \ldots, N T$, the filtration quality depends on the number of observations and the value of the measurement interval $T$.

Results in fig. 3-4 are obtained under $N=40$ and $T \cdot T_{0}^{-1}=0.04$.

\section{CONCLUSIONS}

Thus, we can draw the following conclusions from the above:

1) correction of the controller parameters according to expressions (8)-(13) reduces duration of the transient process in the closed-loop ACS;

2) for an object approximated by two relaxation circuits, the controller parameters can be changed 
according to formulae (8)-(13), if time constants of the circuits fulfill the condition $T_{02} \cdot T_{01}^{-1} \leq 0.2$;

3) correction should be performed in the time moment determined from $\dot{X}\left(t_{\mathrm{n}}\right)=0$;

4) the controller parameters should be corrected even if they are optimal;

5) the polynomial representation degree of the filter should be no lower than 2 , i.e. $m \geq 2$;

6) filtration is satisfactory if the fluctuation of the observed input signal because of noise does not exceed $25 \%$ of its absolute value.

\section{REFERENCES}

1. Protsuto V. S. Avtomatizirovannyye sistemy upravleniya tekhnologicheskimi protsessami obogatitel'nykh fabric. Moscow, Nedra, 1987, 253 p.

2. Barskiy L. A., Kozin V. Z. Sistemnyy analiz v obogashchenii poleznykh iskopayemykh. Moscow, Nedra, $1978,486 \mathrm{p}$.

3. Morkun V. S., Morkun N. V. Estimation of the crushed ore particles density in the pulp flow based on the dynamic effects of high-energy. Ultrasound. Archives of acoustics, 2018, Vol. 43, Issue 1, pp. 61-67.

4. Maryuta A. N., Kachan Yu. G. Avtomaticheskiy kontrol' granulometricheskogo sostava sypuchikh materialov [Text]. Kiyev, Donetsk, Vishcha shkola, 1977, 119 p.

5. Golik V., Komashchenko V., Morkun V. Innovative technologies of metal extraction from the ore processing mill tailings and their integrated use, Metallurgical and Mining Industry, 2015, No. 3, pp. 49-52. URL: http://www.metaljournal.com.ua/assets/Journal/englishedition/MMI 2015 3/007\%20Golik\%20Vladimir.pdf.

6. Morkun V. S. Morkun N. V., Tron V. V. Automatic control of the ore suspension solid phase parameters using highenergy ultrasound, Radio electronics, Computer science, Control, 2017, No. 3, pp. 175-182. DOI: https://doi.org/10.15588/1607-3274-2017-3-20

7. Morkun V., Morkun N., Pikilnyak A. The study of volume ultrasonic waves propagation in the gas-containing iron ore pulp [Electronic resource], Ultrasonics, 2015, Vol. 56, pp. 340-343. URL: http://www.sciencedirect.com/science/ article/pii/S0041624X14002443.
8. Maryuta A. N., Davidkovich A. N., Gulenko T. I., Kondratets V. A. Avtomatizatsiya protsessov obogashcheniya rud. Kiyev, Tekhnika, 1972, 140 p.

9. Morkun V. Morkun N., Pikilnyak A. Ultrasonic facilities complex for grinding and ore classification process control, 37 th IEEE International Conference on Electronics and Nanotechnology (ELNANO). Kyiv, Ukraine, Date: APR 18-20, 2017. pp. 409-413.

10. Golik V., Komashchenko V., Morkun V. Feasibility of using the mill tailings for preparation of self-hardening mixtures, Metallurgical and Mining Industry, 2015, No. 3, pp. 38-41. URL: http://www.metaljournal.com.ua/ assets/Journal/english-edition/MMI_2015_3/004\% 20Golik\%20Vladimir.pdf

11. Anderson B. D. O., Moore J. B. Linear optimal control. Prentice-Hall, Englewood Cliffs, 1971, 413 p.

12. Boyd S. P., Barratt C. H. Linear controller design: limits of performance, Prentice Hall, Englewood Cliffs, NJ, 1991, $426 \mathrm{p}$.

13. Morkun V. S., Semerikov S. O., Hryshchenko S. M. Content and teaching technology of course "ecological geoinformatics" in training of future mining engineers, Information technologies and learning tools, 2017, Vol. 57, No. 1,pp. 115-125.

14. Doyle J. C., Francis B. A., Tannenbaum A. R. Feedback control theory, Macmillan, New York, 1992, $219 \mathrm{p}$.

15. Tao G. Adaptive control design and analysis. Hoboken, Wiley-Interscience, 2003, 618 p.

16. Ioannou P. A., Fidan B. Adaptive control tutorial. Philadelphia, Society for Industrial and Applied Mathematics, 2006, 389 p.

17. Morkun V. S., Potapov V. N. Algoritmy adaptivnogo upravleniya tekhnologicheskimi protsessami obogashcheniya poleznykh ickopayemykh, Obogashcheniye rud, 1986, No. 5, pp. 44-46.

18. Desoer C. A., Vidyasagar M. Feedback systems: inputoutput properties [Text]. New York, Academic Press, 1975, $264 \mathrm{p}$.

19. Doyle J. C. Analysis of feedback systems with structured uncertainties, IEE Proceedings D (Control Theory and Applications), 1982, Volume 129, Issue 6, pp. 242-250.

20. Skogestad S., Postlethwaite I. Multivariable feedback control - analysis and design. Chichester, John Wiley and Sons Ltd., 1995, 585 p.

Received 08.05.2018 Accepted 25.06.2018.

УДК 681.513.6: 622.023.2

\section{СИНТЕЗ ПЕРЕШКОДОЗАХИЩЕНОГО АЛГОРИТМУ ДЛЯ АДАПТИВНОГО КЕРУВАННЯ ПРОЦЕСОМ ЗБАГАЧЕННЯ РУДИ}

Моркун В. С. - д-р техн. наук, професор, проректор з наукової роботи Криворізького національного університету, Кривий Ріг, Україна.

Моркун Н. В. - д-р техн. наук, доцент, завідувач кафедри автоматизації, комп’ютерних наук і технологій Криворізького національного університету, Кривий Ріг, Україна.

Грищенко С. М. - канд. пед. наук, завідувач аспірантури та докторантури Криворізького національного університету, Кривий Ріг, Україна.

Тронь В. В. - канд. техн. наук, доцент, доцент кафедри автоматизації, комп'ютерних наук і технологій Криворізького національного університету, Кривий Ріг, Україна.

\section{АНОТАЦІ}

Актуальність. Облік характеристик перехідного процесу для поточної виробничої ситуації, тобто фактично статичних і динамічних характеристик об'єкту управління при формуванні керуючих впливів в системах автоматичного регулювання процесів подрібнення-класифікації руд є одним з перспективних шляхів підвищення їх ефективності. 
В результаті коливань характеристик вихідної сировини і стану технологічного обладнання, а також при змінах величин завдання в замкнутих системах автоматичного регулювання (САР) виникають перехідні процеси, завдяки яким гранулометричний склад вихідних продуктів для подрібнення та класифікувальних агрегатів змінюється в широких межах. Ця обставина призводить до додаткових витрат корисного компоненту.

Тривалість перехідних процесів залежить від того, наскільки точно поточний стан об'єкта управління (його статичні та динамічні характеристики) відповідає параметрам регулятора в ЗАР. Звідси випливає необхідність періодичного підлаштування параметрів регулятора, що найкращим чином здійснюється в адаптивних 3АР.

Запропоновано алгоритм перешкодозахищеності корекцій параметрів регулятора замкнутої системи авторегулювання, заснований на попередній ідентифікації статичних і динамічних характеристик об'єкту управління за параметрами, який почався в замкнутій САР перехідного процесу. Визначено межі його застосовності в умовах збагачувальної фабрики.

Об'єкт. Розробка перешкодозахисного алгоритму адаптивного управління об'єктами зі змінними статичними та динамічними характеристиками на базі інформацій про величину контрольованого параметру і швидкості його зміни в початковій стадії перехідних процесів в замкнутій САР.

Метод. Виконано аналіз існуючих підходів і методів оптимізації управління процесом збагачення руди для обгрунтування актуальності, цілей i завдань досліджень. Методами аналітичного конструювання та комп'ютерного моделювання виконано синтез та аналіз алгоритму адаптації для локальних САР процесів збагачення руди.

Результати. Корекція параметрів ПІ-регулятора відповідно до запропонованого алгоритму значно скорочує час перехідного процесу в замкнутій САР. Корекцію доцільно здійснювати в момент часу, який визначається за умови $\dot{X}\left(t_{\text {п }}\right)=0$ і проводиться навіть в разі його оптимальної настройки. Ступінь поліномного уявлення фільтра повинна бути не нижче 2 , тобто $m \geq 2$, при цьому фільтрація виявляється задовільною, якщо флуктуація спостережуваного вихідного сигналу за рахунок шуму не перевищує $25 \%$ його абсолютного значення.

Висновки. Отримавши в роботі подальший розвиток теорія формування заданих параметрів перехідних процесів в замкнутих системах автоматичного управління об’єктами зі змінними статичними та динамічними характеристиками на базі інформації про величину контрольованого параметру і швидкості його зміни на початковій стадії цих процесів, дозволяє синтезувати адаптивні САР, в яких і при наявності впливів, що обурюють і перешкод в контрольованому сигналі величина неузгодженості в ході перехідного процесу досягає нульового значення за мінімальний час без зміни свого знаку.

КЛЮЧОВІ СЛОВА: замкнута система, регулювання, контроль, алгоритм, перехідна, адаптація, межі дійсності.

УДК 681.513.6: 622.023.2

\section{СИНТЕЗ ПОМЕХОЗАЩИЩЕННОГО АЛГОРИТМА ДЛЯ АДАПТИВНОГО УПРАВЛЕНИЯ ПРОЦЕССОМ ОБОГАЩЕНИЯ РУДЫ}

Моркун В. С. - д-р техн. наук, профессор, проректор по научной работе Криворожского национального университета, Кривой Рог, Украина.

Моркун Н. В. - д-р техн. наук, доцент, заведующая кафедрой автоматизации, компьютерных наук и технологий Криворожского национального университета, Кривой Рог, Украина.

Грищенко С. Н. - канд. пед. наук, заведующая аспирантурой и докторантурой Криворожского национального университета, Кривой Рог, Украина.

Тронь В. В. - канд. техн. наук, доцент, доцент кафедры автоматизации, компьютерных наук и технологий Криворожского национального университета, Кривой Рог, Украина.

\section{АННОТАЦИЯ}

Актуальность. Учет характеристик переходного процесса для текущей производственной ситуации, т.е. фактически статических и динамических характеристик объекта управления при формировании управляющих воздействий в системах автоматического регулирования процессов измельчения-классификации руд является одним из перспективных путей повышения их эффективности.

В результате колебаний характеристик исходного сырья и состояния технологического оборудования, а также при изменениях величины задания в замкнутых системах автоматического регулирования (САР) возникают переходные процессы, в ходе которых гранулометрический состав выходных продуктов измельчительных и классифицирующих агрегатов изменяется в широких пределах. Это обстоятельство приводит к дополнительным потерям полезного компонента.

Длительность переходных процессов зависит от того, насколько точно текущее состояние объекта управления (его статические и динамические характеристики) соответствует настройкам регулятора в САР. Из этого следует необходимость периодической подстройки параметров регулятора, что наилучшим образом осуществляется в адаптивных САР.

Предложен алгоритм помехозащищённой коррекции параметров регулятора замкнутой системы авторегулирования, основанный на предварительной идентификации статических и динамических характеристик объекта управления по параметрам начавшегося в замкнутой САР переходного процесса. Определены границы его применимости в условиях обогатительной фабрики.

Объект. Разработка помехозащищенного алгоритма адаптивного управления объектами с переменными статическими и динамическими характеристиками на базе информации о величине контролируемого параметра и скорости его изменения в начальной стадии переходных процессов в замкнутой САР.

Метод. Выполнен анализ существующих подходов и методов оптимизации управления процессом обогащения руды для обоснования актуальности, целей и задач исследований. Методами аналитического конструирования и компьютерного моделирования выполнены синтез и анализ алгоритма адаптации для локальных САР процессов обогащения руды. 
Результаты. Коррекция параметров ПИ-регулятора в соответствии с предложенным алгоритмом значительно сокращает время переходного процесса в замкнутой САР. Коррекцию целесообразно осуществлять в момент времени, определяемый из условия $\dot{X}\left(t_{\text {п }}\right)=0$, и проводить даже в случае его оптимальной настройки. Степень полиномного представления фильтра должна быть не ниже 2, т.е. $m \geq 2$, при этом фильтрация оказывается удовлетворительной, если флуктуация наблюдаемого выходного сигнала за счет шума не превышает 25 \% его абсолютного значения.

Выводы. Получившая в работе дальнейшее развитие теория формирования заданных параметров переходных процессов в замкнутых системах автоматического управления объектами с изменяющимися статическими и динамическими характеристиками на базе информации о величине контролируемого параметра и скорости его изменения в начальной стадии этих процессов, позволяет синтезировать адаптивные САР, в которых и при наличии возмущающих воздействий и помех в контролируемом сигнале величина рассогласования в ходе переходного процесса достигает нулевого значения за минимальное время без изменения своего знака.

КЛЮЧЕВЫЕ СЛОВА: замкнутая система, регулирование, управление, алгоритм, переходный процесс, адаптация, пределы допустимости.

\section{ЛІТЕРАТУРА / ЛИТЕРАТУРА}

1. Процуто В. С. Автоматизированные системы управления технологическими процессами обогатительных фабрик / В. С. Процуто. - М. : Недра, 1987. $-253 \mathrm{c}$.

2. Барский Л. А. Системный анализ в обогащении полезных ископаемых / Л. А. Барский, В. З. Козин. М.: Недра, 1978. - 486 c.

3. Morkun V. S. Estimation of the crushed ore particles density in the pulp flow based on the dynamic effects of high-energy / V. S. Morkun, N. V. Morkun // Ultrasound. Archives of acoustics. - 2018. - Vol. 43, Issue 1. - P. 6167.

4. Марюта А. Н. Автоматический контроль гранулометрического состава сыпучих материалов / А. Н. Марюта, Ю. Г. Качан. - Киев; Донецк : Вища школа, 1977. - 119 с.

5. Golik V. Innovative technologies of metal extraction from the ore processing mill tailings and their integrated use / V. Golik, V. Komashchenko, V. Morkun // Metallurgical and Mining Industry. - 2015. - No. 3. - P. 49-52. URL http://www.

metaljournal.com.ua/assets/Journal/english-edition/ MMI 2015_3/007\%20Golik\%20Vladimir.pdf.

6. Morkun V. $\overline{\mathrm{S}}$. Automatic control of the ore suspension solid phase parameters using high-energy ultrasound / V. S. Morkun, N. V. Morkun, V. V. Tron // Radio electronics, Computer science, Control. - 2017. - № 3. P. 175-182. DOI: https://doi.org/10.15588/1607-32742017-3-20

7. Morkun V. The study of volume ultrasonic waves propagation in the gas-containing iron ore pulp [Electronic resource] / V. Morkun, N. Morkun, A. Pikilnyak // Ultrasonics. - 2015. - Vol. 56. - P. 340-343. URL: $\mathrm{http} / / / \mathrm{www}$. sciencedirect.com/science/ article/pii/S0041624X14002443.

8. Марюта А. Н. Автоматизация процессов обогащения руд / А. Н. Марюта, А. Н. Давидкович, Т. И. Гуленко, В. А. Кондратец. - Киев : Техніка, 1972. - 140 с.

9. Morkun V. Ultrasonic facilities complex for grinding and ore classification process control / V. Morkun, N. Morkun, A. Pikilnyak // 37th IEEE International Conference on
Electronics and Nanotechnology (ELNANO) Kyiv, Ukraine, Date: APR 18-20. - 2017. - P. 409-413.

10. Golik V. Feasibility of using the mill tailings for preparation of self-hardening mixtures / V. Golik, V. Komashchenko, V. Morkun // Metallurgical and Mining Industry. - 2015. - No. 3. - P. 38-41. URL: http://www.metaljournal.com.ua/ assets/Journal/english-edition/MMI 2015 3/004\% 20Golik\%20Vladimir.pdf

11. Anderson B. D. O. Linear optimal control / B. D. O. Anderson, J. B. Moore. - Prentice-Hall, Englewood Cliffs, 1971. - 413 p.

12. Boyd S. P. Linear controller design: limits of performance [Text] / S. P. Boyd, C. H.Barratt // Prentice Hall, Englewood Cliffs, NJ, 1991. - 426 p.

13. Morkun V. S. Content and teaching technology of course "ecological geoinformatics" in training of future mining engineers / V. S. Morkun, S. O. Semerikov, S. M. Hryshchenko // Information technologies and learning tools. -2017 . - Vol. 57, No. 1. - P. 115-125.

14. Doyle J. C. Feedback control theory / J. C. Doyle, B. A. Francis, A. R. Tannenbaum. - Macmillan, New York, 1992. $-219 \mathrm{p}$.

15. Tao G. Adaptive control design and analysis / G. Tao. Hoboken : Wiley-Interscience, 2003. - 618 p.

16. Ioannou P. A. Adaptive control tutorial / P. A. Ioannou, B. Fidan. - Philadelphia : Society for Industrial and Applied Mathematics, 2006. -389 p.

17. Моркун В. С. Алгоритмы адаптивного управления технологическими процессами обогащения полезных ископаемых / В. С. Моркун, В. Н. Потапов // Обогащение руд. - 1986. - № 5. - С. 44-46.

18. Desoer C. A. Feedback systems: input-output properties / C. A. Desoer, M. Vidyasagar. - New York : Academic Press, 1975. -264 p.

19. Doyle J. C. Analysis of feedback systems with structured uncertainties / J. C. Doyle // IEE Proceedings D (Control Theory and Applications). - 1982. - Volume 129, Issue 6. - P. 242-250.

20. Skogestad S. Multivariable feedback control - analysis and design / S. Skogestad, I. Postlethwaite. - Chichester : John Wiley and Sons Ltd., 1995. - 585 p. 